\title{
Copper Recovery from Printed Circuit Board by Carbonization
}

\author{
Hiroyuki ONo, Gjergj DodBIBA and Toyohisa FUJITA \\ Department of Systems Innovation, School of Engineering, The University of Tokyo \\ 7-3-1 Hongo, Bunkyo-ku, Tokyo 113-8656, Japan \\ E-mail:tt087274@mail.ecc.u-tokyo.ac.jp
}

\begin{abstract}
In an attempt to raise the copper grade of Printed Circuit board (PCB) by removing other components, carbonization treatment was investigated. The crushed PCB without surface-mounted parts was carbonized under nitrogen atmosphere. After screening, the char was classified by size into oversized pieces, undersized pieces and powder. The copper foil and glass fiber pieces were liberated and collected in undersized fraction. The liberation of copper foil from the oversized pieces was also investigated. The copper foil was liberated easily from glass fiber by stamping treatment. Liberation rate of copper foil was high at high carbonized temperature. The experimental results indicated that $90 \%$ of oversized char was liberated and the copper foil recovery from PCB carbonized at $1073 \mathrm{~K}$ was $110 \mathrm{~kg} / \mathrm{t}$. The copper recovery from char powder by flotation was also investigated. $15 \%$ of the copper grade and $80 \%$ of the copper recovery were obtained.
\end{abstract}

Key Words : Carbonization, Printed Circuit Board, Recycling, flotation

\section{INTRODUCTION}

Recently, it has been required to recycle valuable resources from wastes to conserve limited resources. Especially Waste Electrical and Electronic Equipments (WEEEs) should be recycled because they have many kinds of valuable materials. Most WEEEs include Printed Circuit Boards (PCBs). In Japan, about 30 million $\mathrm{m}^{2}$ per year of PCB has been produced [1]. PCBs are normally separated from WEEEs and picked up by hand and sold to non-ferrous metal users because PCBs include high grade of copper and other precious metals such as gold, silver and palladium [2]. However, PCB also has impurities such as silicon, aluminum and calcium, which become slag materials during a non-ferrous smelting process, and other harmful elements such as lead, bromine and antimony. Low grade PCBs are sold after removal of invaluable parts or sometimes landfilled without any treatment.

Copper foil and glass fiber form multi-layered structure in PCB. PCB is produced by heating and pressurizing multi-layered copper foil and glass fiber impregnated by epoxy resin. Copper foils are so closely attached with glass fiber that it is difficult to separate copper foil from PCB.

Metal recovery from PCB has been studied by several methods such as crushing, separation method and leaching method [3-7]. Glass fiber recovery has also been studied [8].

Pyrolysis of PCB has been also studied but these studies were mainly investigated about the pyrolysis gas and char constituent [9-12]. In this paper, carbonization treatment was studied to remove glass fiber from low grade PCBs. Carbonization is a pyrolysis treatment of solids in absence of oxygen. Resins in PCB are pyrolyzed and metals are not oxidized by carbonization. It is therefore expected to recover copper efficiently in post process.

\section{EXPERIMENTAL METHOD}

\subsection{Carbonization and separation}

PCBs of 4 to $20 \mathrm{~mm}$ in size, which were crushed by using a biaxial shear cutter and rotor crusher, were used for experiment. Surface mounted parts were removed from crushed PCBs. $100 \mathrm{~g}$ of crushed PCB was spread over a stainless tray made of SUS430 and set in an electric furnace with $17 \mathrm{~L}$ of furnace volume. PCBs were heated with $50 \mathrm{~K} / \mathrm{min}$. of heating rate and carbonized at prescribed temperature for $1 \mathrm{hr} .15 \mathrm{~L} / \mathrm{min}$. of nitrogen gas was blown into the furnace to keep oxygen concentration at $2.5 \%$ due to air leakage into the furnace. PCB char was air-cooled after carbonization.

PCB char was screened by sieves and weight ratio with each particle size was measured. From char pieces with size over $4 \mathrm{~mm}$,

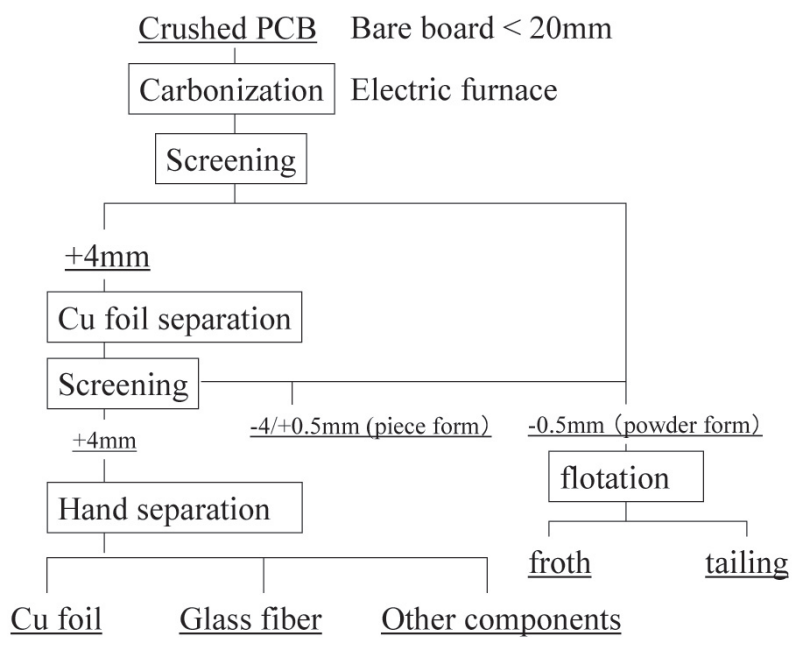

Figure 1. Experimental flowsheet 
copper foil, glass fiber and other parts were hand-picked and recovery of copper foil was measured.

Separation tests were conducted for different parts in which copper foil and glass fiber keep multi-layered form. The aim was to liberate copper foil with cutter mill, ball mill and stamp mill. $20 \mathrm{~g}$ of multi-layered parts was tested with each test. Parts with the size over $4 \mathrm{~mm}$ were screened after separation test and liberated copper foil and glass fiber were hand-picked to measure each weight.

After measuring the weight, several elements such as copper, silicon and calcium were analyzed with wavelength-dispersive X-ray fluorescence spectrometer (XRF, Rigaku Supermini) and copper grade and recovery were calculated. Figure 1 shows the experimental flow.

\subsection{Flotation}

For the powder of PCB char carbonized at $1073 \mathrm{~K}$ with size under $0.5 \mathrm{~mm}$, copper upgrade was investigated by flotation. Chemical compounds of the char were identified by X-ray diffraction (XRD) analyzer (Rigaku MiniFlex). Element distributions on the char surface were investigated under scanning electron microscope (SEM) equipped with an energy dispersive X-ray (EDX) analyzer (Hitachi S-4200/Kevex Super Dry).

Char was ground with pestle and mortar to prepare powder of particle size under 150, 75 and $44 \mu \mathrm{m}$. Flotation reagents were $0.5 \mathrm{~mol} / \mathrm{L}$ sulfuric acid and $1 \mathrm{~mol} / \mathrm{L}$ sodium hydroxide as $\mathrm{pH}$ adjustor, sodium hydrogen sulfide (NaHS, purity $70 \%$ ) as activator, Potassium Amyl Xanthate (PAX, purity 90\%) as collector and Methyl Isobutyl Carbinol (MIBC) as frother. The dosage of MIBC was $1.4 \mathrm{~kg} / \mathrm{t}$. NaHS and PAX are dissolved in ionic exchanged water to obtain 5 mass $\%$ and 1 mass $\%$ solution.

Denver type flotation cell of $200 \times 10^{-6} \mathrm{~m}^{3}$ was used. $5 \mathrm{~g}$ of powder was added in $150 \times 10^{-6} \mathrm{~m}^{3}$ of deionized water while stirring by using an impeller at $350 \mathrm{rpm}$. Next, NaHS solution was added. After $15 \mathrm{~min}$, PAX was added and $\mathrm{pH}$ was adjusted. After $15 \mathrm{~min}$., MIBC was added and $1.5 \times 10^{-6} \mathrm{~m}^{3} / \mathrm{min}$. of air was introduced under the cell. The floated froth was collected for $10 \mathrm{~min}$. The froth and tailing were filtered and dried at $363 \mathrm{~K}$ for $12 \mathrm{hr}$.

After measuring the weight, copper, silicon were analyzed with XRF (Rigaku Supermini) and copper grade and recovery were calculated.

\section{RESULTS AND DISCUSSIONS}

\subsection{Carbonization and separation}

Table 1 shows the breakdown of the char. Char with size over $4 \mathrm{~mm}$ was composed of copper foil, glass fiber, other parts, and multi-layered parts at any carbonized temperature. On the other hand, copper foil and glass fiber were liberated among char with size under $4 \mathrm{~mm}$ by visual check.

It is expected to recover copper foil efficiently from char with size under $4 \mathrm{~mm}$ with eddy current separator or electrostatic separator.

As a result of separation tests for multi-layered parts, both copper foil and glass fiber were pulverized when cutter mill was employed. Most parts kept multi-layered structure, when the ball mill was employed. Multi-layered parts decreased gradually with back and forth shaker, but most parts were pulverized by abrasion and copper foil hardly increased.

On the other hand, copper foil and glass fiber were liberated by stamping treatment. Figure 2 shows the result of separation test by stamping with pestle at a rate of 150 times per min. Multi-layered parts was gradually separated into copper foil and glass fiber. It was concluded that stamping treatment was the best way for copper foil liberation.

Copper foil liberation of char carbonized at each temperature was compared. Table 2 shows the breakdown of the char after stamping treatment. Some multi-layered parts remained even at $673 \mathrm{~K}$ of carbonization temperature. The amount of material with size over $4 \mathrm{~mm}$ was decreasing with increasing in carbonization temperature. This is because char became brittle at higher carbonization temperature. Glass fiber was liberated most from the char carbonized at $873 \mathrm{~K}$. Multi-layered parts were broken down most and glass fiber was selectively pulverized to powder for the char carbonized at $1073 \mathrm{~K}$.

Table 3 shows the copper and silicon concentrations and distributions of each particle size and classification of the char. Up to $42 \%$ of initial copper amount was separated as copper foil at $673 \mathrm{~K}$ of carbonization temperature. In the same way, up to $45 \%$ of silicon was separated as glass fiber.

Figure 3 shows the copper grade of the char after glass fiber removal. Copper grade was raised from 13 to $30 \%$ at $873 \mathrm{~K}$ of carbonization. It was concluded that carbonization and liberation process was effective for the copper recovery from the low grade PCB.

\subsection{Flotation for powder of PCB char}

Copper grade of char carbonized at $1073 \mathrm{~K}$ with size under

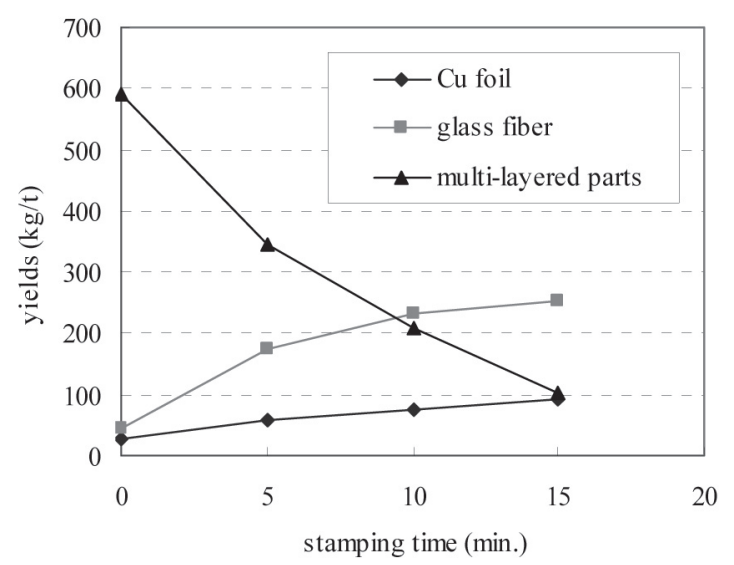

Figure 2. Weight changes by stamping treatment for the char with size over $4 \mathrm{~mm}$ carbonized at $673 \mathrm{~K}$

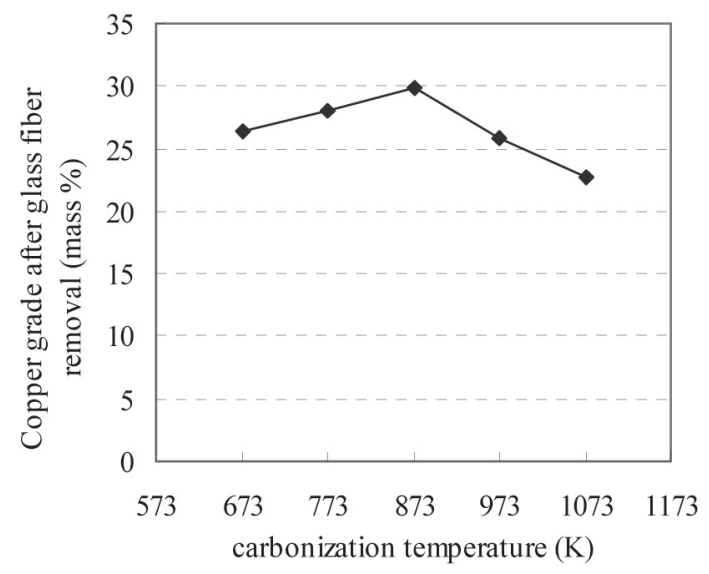

Figure 3. Copper grade of the char after glass fiber removal 
Table 1. The breakdown of the char before stamping treatment.

\begin{tabular}{|c|c|c|c|c|c|c|c|c|c|c|}
\hline \multirow{3}{*}{$\begin{array}{l}\text { Carbonization } \\
\text { temperature }\end{array}$} & \multirow{3}{*}{$\begin{array}{l}\text { residual } \\
\text { ratio }\end{array}$} & \multicolumn{9}{|c|}{ particle size / mm } \\
\hline & & $+4 \mathrm{~mm}$ & & & & $-4 /+2$ & $-2 /+1$ & $-1 /+0.5$ & $-0.5 /+0.15$ & -0.15 \\
\hline & & total & $\mathrm{Cu}$ foil & Glass fiber & $\begin{array}{l}\text { multi- } \\
\text { layered } \\
\text { parts }\end{array}$ & total & total & total & total & total \\
\hline $\mathrm{K}$ & $\mathrm{kg} / \mathrm{t}$ & $\mathrm{kg} / \mathrm{t}$ & $\mathrm{kg} / \mathrm{t}$ & $\mathrm{kg} / \mathrm{t}$ & $\mathrm{kg} / \mathrm{t}$ & $\mathrm{kg} / \mathrm{t}$ & $\mathrm{kg} / \mathrm{t}$ & $\mathrm{kg} / \mathrm{t}$ & $\mathrm{kg} / \mathrm{t}$ & $\mathrm{kg} / \mathrm{t}$ \\
\hline 673 & 738 & 663 & 28 & 44 & 591 & 20 & 21 & 17 & 14 & 7 \\
\hline 773 & 680 & 573 & 37 & 107 & 429 & 7 & 45 & 26 & 21 & 10 \\
\hline 873 & 651 & 552 & 38 & 179 & 334 & 18 & 27 & 23 & 23 & 9 \\
\hline 973 & 653 & 477 & 44 & 145 & 288 & 35 & 31 & 35 & 47 & 30 \\
\hline 1073 & 654 & 422 & 31 & 91 & 300 & 84 & 46 & 37 & 42 & 25 \\
\hline
\end{tabular}

Table 2. The breakdown of the char after stamping treatment.

\begin{tabular}{|c|c|c|c|c|c|c|c|c|c|c|}
\hline \multirow[t]{3}{*}{$\begin{array}{c}\text { Carbonization } \\
\text { temperature }\end{array}$} & \multirow[t]{3}{*}{$\begin{array}{l}\text { residual } \\
\text { ratio }\end{array}$} & \multicolumn{9}{|c|}{ particle size / $\mathrm{mm}$} \\
\hline & & $+4 \mathrm{~mm}$ & & & & $-4 /+2$ & $-2 /+1$ & $-1 /+0.5$ & $-0.5 /+0.15$ & -0.15 \\
\hline & & total & $\mathrm{Cu}$ foil & Glass fiber & $\begin{array}{l}\text { multi- } \\
\text { layered } \\
\text { parts }\end{array}$ & total & total & total & total & total \\
\hline $\mathrm{K}$ & $\mathrm{kg} / \mathrm{t}$ & $\mathrm{kg} / \mathrm{t}$ & $\mathrm{kg} / \mathrm{t}$ & $\mathrm{kg} / \mathrm{t}$ & $\mathrm{kg} / \mathrm{t}$ & $\mathrm{kg} / \mathrm{t}$ & $\mathrm{kg} / \mathrm{t}$ & $\mathrm{kg} / \mathrm{t}$ & $\mathrm{kg} / \mathrm{t}$ & $\mathrm{kg} / \mathrm{t}$ \\
\hline 673 & 738 & 448 & 91 & 254 & 103 & 42 & 54 & 44 & 66 & 84 \\
\hline 773 & 680 & 396 & 74 & 223 & 99 & 18 & 82 & 61 & 80 & 41 \\
\hline 873 & 651 & 395 & 85 & 222 & 88 & 28 & 57 & 60 & 51 & 60 \\
\hline 973 & 653 & 272 & 103 & 159 & 10 & 43 & 50 & 45 & 141 & 100 \\
\hline 1073 & 654 & 189 & 98 & 91 & 0 & 89 & 64 & 51 & 124 & 137 \\
\hline
\end{tabular}

Table 3. $\mathrm{Cu}$, Si concentration and distribution of each particle size and classification.

\begin{tabular}{|c|c|c|c|c|c|c|c|c|}
\hline \multirow{2}{*}{$\begin{array}{c}\text { carbonization } \\
\text { temperature } \\
\mathrm{K} \\
\end{array}$} & \multirow{2}{*}{$\begin{array}{l}\text { stamping } \\
\text { time } \\
\text { min. } \\
\end{array}$} & \multicolumn{2}{|l|}{ particle size } & \multirow{2}{*}{$\begin{array}{c}\text { weight } \\
\mathrm{kg} / \mathrm{t}\end{array}$} & \multicolumn{2}{|c|}{ concentration (mass \%) } & \multicolumn{2}{|c|}{ distribution $(\%)$} \\
\hline & & \multicolumn{2}{|r|}{ classification } & & $\mathrm{Cu}$ & $\mathrm{Si}$ & $\mathrm{Cu}$ & $\mathrm{Si}$ \\
\hline & & \multicolumn{2}{|c|}{ cruched PCB board } & 1000 & 17.0 & 5.5 & 100 & 100 \\
\hline \multirow[t]{8}{*}{673} & \multirow[t]{8}{*}{15} & total & & 738 & 19.9 & 7.1 & 100 & 100 \\
\hline & & $-0.5 \mathrm{~mm}$ & & 150 & 10.2 & 7.2 & 10 & 21 \\
\hline & & $-1 /+0.5 \mathrm{~mm}$ & & 44 & 18.1 & 5.8 & 5 & 5 \\
\hline & & $-4 /+1 \mathrm{~mm}$ & & 96 & 25.1 & 5.6 & 16 & 10 \\
\hline & & $+4 \mathrm{~mm}$ & & 448 & 22.3 & 7.4 & 68 & 64 \\
\hline & & \multirow{3}{*}{$\begin{array}{c}\text { breakdown } \\
\text { of }+4 \mathrm{~mm}\end{array}$} & copper foil & 91 & 68.6 & 2.1 & 42 & 4 \\
\hline & & & glass fiber & 254 & 4.3 & 9.3 & 8 & 45 \\
\hline & & & others & 103 & 25.5 & 7.5 & 18 & 15 \\
\hline \multirow[t]{8}{*}{873} & \multirow[t]{8}{*}{5} & total & & 651 & 21.0 & 8.4 & 100 & 100 \\
\hline & & $-0.5 \mathrm{~mm}$ & & 111 & 13.0 & 8.9 & 11 & 18 \\
\hline & & $-1 /+0.5 \mathrm{~mm}$ & & 60 & 27.0 & 7.5 & 12 & 8 \\
\hline & & $-4 /+1 \mathrm{~mm}$ & & 85 & 25.7 & 9.4 & 16 & 15 \\
\hline & & $+4 \mathrm{~mm}$ & & 395 & 21.4 & 8.1 & 62 & 59 \\
\hline & & & copper foil & 85 & 66.2 & 3.9 & 41 & 6 \\
\hline & & of $+4 \mathrm{~mm}$ & glass fiber & 222 & 2.8 & 10.0 & 5 & 41 \\
\hline & & or +4mm & others & 88 & 24.8 & 7.2 & 16 & 12 \\
\hline
\end{tabular}

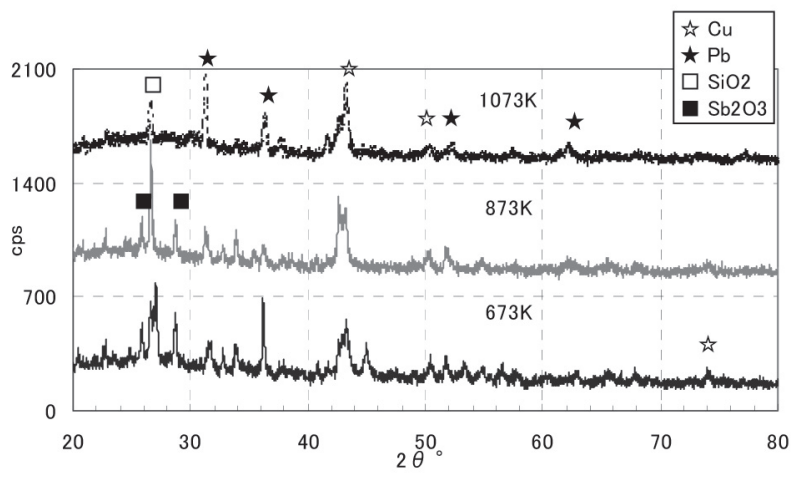

Figure 4. XRD patterns of PCB char with size under $0.5 \mathrm{~mm}$
$0.5 \mathrm{~mm}$ was $10 \%$. Figure 4 shows the XRD patterns of the char with size under $0.5 \mathrm{~mm}$ carbonized at each temperature. The peak of $\mathrm{Cu}, \mathrm{Pb}, \mathrm{SiO}_{2}$ and $\mathrm{Sb}_{2} \mathrm{O}_{3}$ were observed.

Figure 5 shows the SEM images and elemental mappings of the char with size under $0.5 \mathrm{~mm}$ carbonized at $1073 \mathrm{~K}$. It was expected that copper particle was liberated with $\mathrm{SiO}_{2}$ particle because copper distribution was not matched with silicon distribution. Therefore, flotation after sulfurization would be effective for the upgrade of copper.

Figure 6 shows the grade and recovery of copper in froth as a function of NaHS dosage. The flotation tests were carried out 
for the powder grounded to particle size under $150 \mu \mathrm{m}$ by adding $10 \mathrm{~kg} / \mathrm{t} \mathrm{PAX}$ and adjusting $\mathrm{pH}$ at 6 . NaHS dosage in the 5 to 50 $\mathrm{kg} / \mathrm{t}$ range had little effects on copper grade and recovery. It was therefore concluded that $5 \mathrm{~kg} / \mathrm{t}$ of NaHS was enough.

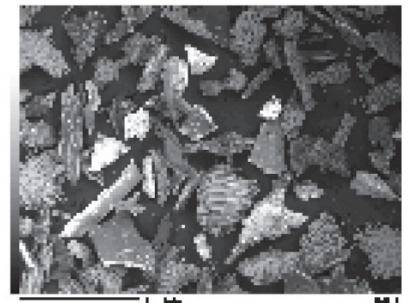

a) $\operatorname{char}(\times 40)$

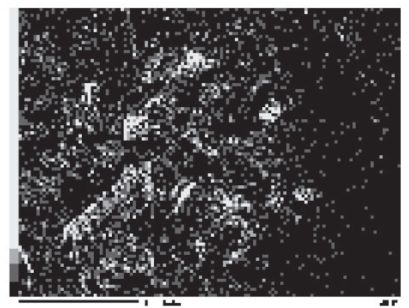

c) Si mapping

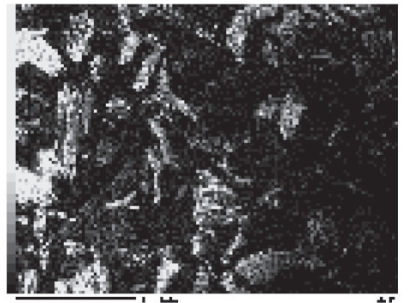

b) $\mathrm{Cu}$ mapping

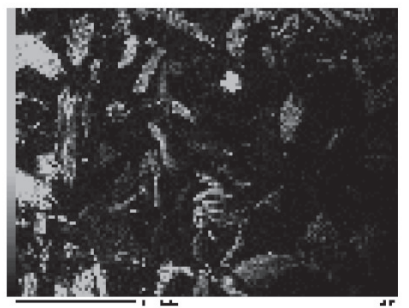

d) Ca mapping
Figure 5. SEM images and elemental mappings of $\mathrm{Cu}, \mathrm{Si}, \mathrm{Ca}$, by EDS

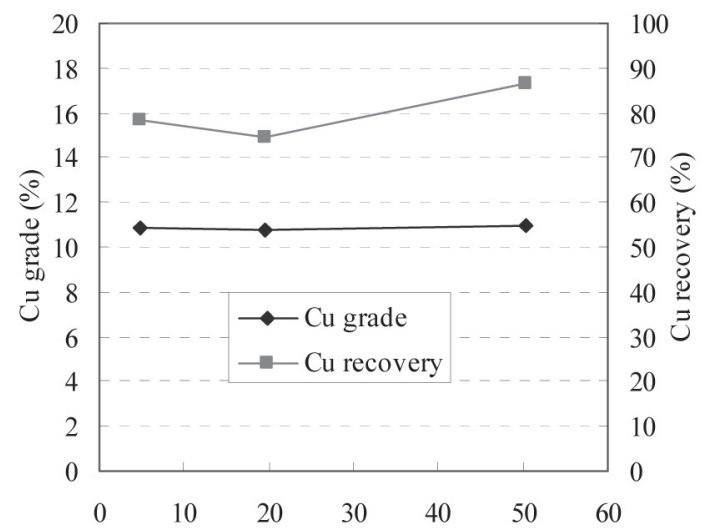

Figure 6. Effect of NaHS dosage on the flotation (particle size under $150 \mu \mathrm{m}, \mathrm{pH} 6,10 \mathrm{~kg} / \mathrm{t} \mathrm{PAX})$

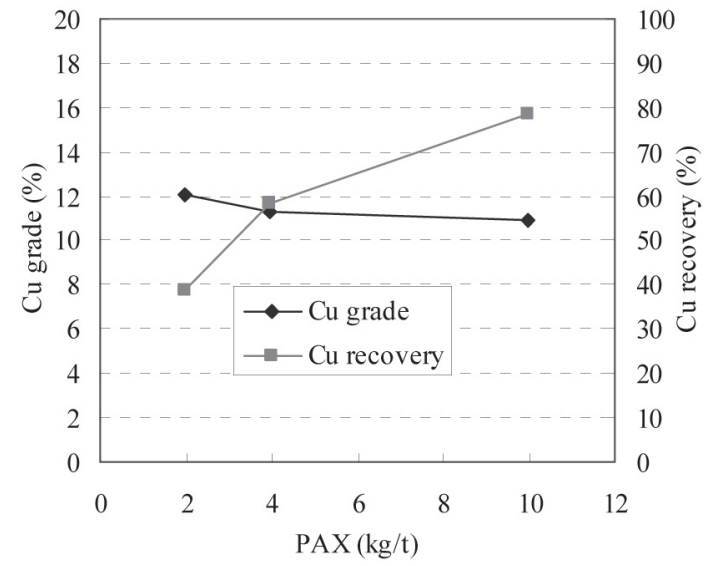

Figure 7. Effect of PAX dosage on the flotation (particle size under $150 \mu$ $\mathrm{m}, \mathrm{pH} 6,5 \mathrm{~kg} / \mathrm{t} \mathrm{NaHS})$
Figure 7 shows the grade and recovery of copper in froth as a function of PAX dosage. The flotation tests were carried out for the powder grounded to particle size under $150 \mu \mathrm{m}$ by adding 5 $\mathrm{kg} / \mathrm{t} \mathrm{NaHS}$ and adjusting $\mathrm{pH}$ at 6 . The recovery of copper increased with increasing PAX dosage from 2 to $10 \mathrm{~kg} / \mathrm{t}$, but the grade slightly decreased. Thus, it was concluded that the optimum dosage of PAX was $10 \mathrm{~kg} / \mathrm{t}$.

Figure 8 shows the grade and recovery of copper in froth as a function of $\mathrm{pH}$. The flotation tests were carried out for the powder grounded to particle size under $150 \mu \mathrm{m}$ by adding 5 $\mathrm{kg} / \mathrm{t} \mathrm{NaHS}$ and $10 \mathrm{~kg} / \mathrm{t}$ PAX. The recovery was highest and the grade increased from 10 to $12 \%$ at $\mathrm{pH} 10$. No $\mathrm{pH}$ adjuster was added at $\mathrm{pH} 10$. Considering the grade, recovery and reagent dosage, it was concluded that optimum $\mathrm{pH}$ was 10 .

Figure 9 shows the grade and recovery of copper in froth as a function of grinding particle size. The flotation tests were carried out by adding $5 \mathrm{~kg} / \mathrm{t} \mathrm{NaHS}$ and $10 \mathrm{~kg} / \mathrm{t} \mathrm{PAX}$ adjusting at $\mathrm{pH} 10$. The grade increased with the smaller particle size, but the recovery decreased. Considering the grade and recovery, under $75 \mu \mathrm{m}$ was optimum grinding size. At this optimum condition, the copper grade increased from 10 to $15 \%$, the copper recovery was $80 \%$, whereas silicon and calcium removal rate were both $55 \%$. Though this copper grade was not enough to be used as raw material for copper smelting process, the flotation was effective for the recovery of copper from the powder of $\mathrm{PCB}$ char.

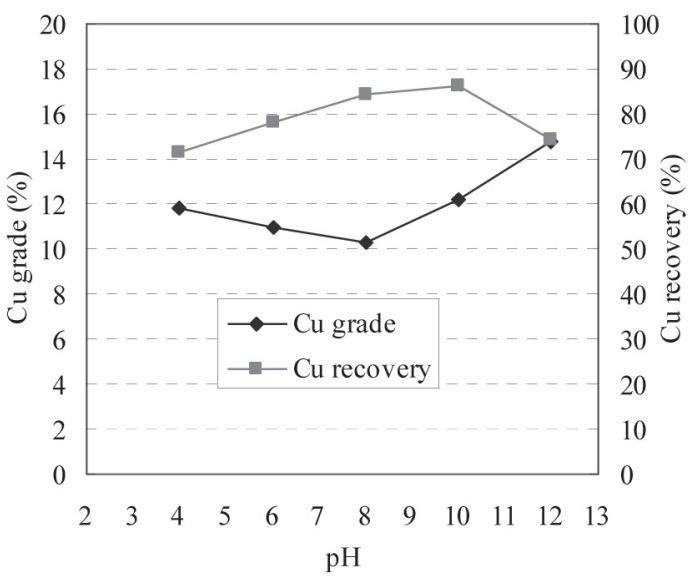

Figure 8. Effect of $\mathrm{pH}$ on the flotation (particle size under $150 \mu \mathrm{m}, 5 \mathrm{~kg} / \mathrm{t}$ $\mathrm{NaHS}, 10 \mathrm{~kg} / \mathrm{tPAX})$

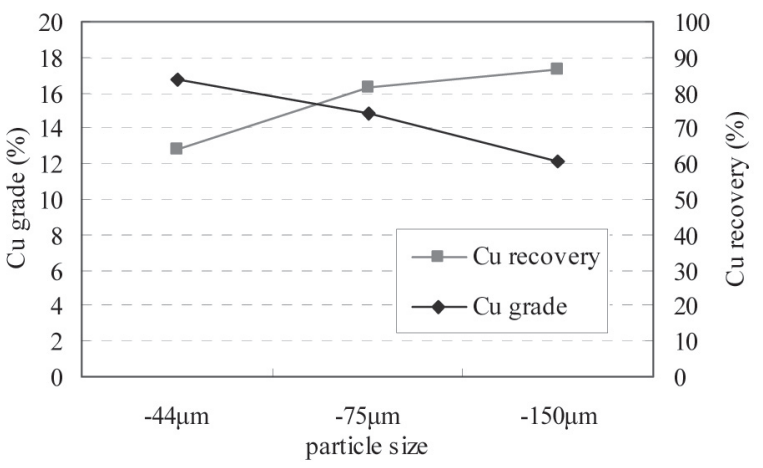

Figure 9. Effect of grinding particle size on the flotation $(\mathrm{pH} 10,5 \mathrm{~kg} / \mathrm{t}$ NaHS, $10 \mathrm{~kg} / \mathrm{t}$ PAX) 


\section{CONCLUSION}

Carbonization and liberation treatment were studied for PCB to raise copper grade and remove slag components. Copper foil could be liberated from carbonized PCB by stamping treatment. Glass fibers carbonized at $1073 \mathrm{~K}$ were pulverized selectively. The largest amounts of glass fibers were liberated at 773 and $873 \mathrm{~K}$ of carbonization temperature. Copper grade was raised from 13 to $30 \%$ after removing glass fiber from the char, carbonized at $873 \mathrm{~K}$. Copper grade was raised from 10 to $15 \%$ by flotation of char powder, carbonized at $1073 \mathrm{~K}$ with size smaller than $0.5 \mathrm{~mm}$ and $80 \%$ of the copper was recovered under the following conditions: particle size under $75 \mu \mathrm{m}, 5 \mathrm{~kg} / \mathrm{t}$ of NaHS, $10 \mathrm{~kg} / \mathrm{t}$ of PAX and $\mathrm{pH}$ 10.

\section{Acknowledgments}

Authors acknowledge DOWA ECO-SYSTEM CO., LTD. for the sample they provided and technical assistance. A part of this work was conducted in Center for Nano Lithography \& Analysis and supported through the Global COE Program, "Global Center of Excellence for Mechanical Systems Innovation," at the University of Tokyo by the Ministry of Education, Culture, Sports, Science and Technology (MEXT), Japan.

\section{References}

[1] Ministry of Economy, Trade and Industry in Japan, Statistics of Machine, (2008).

[2] Jirang Cui, Lifeng Zhang, "Metallurgical recovery of metals from electronic waste: A review" Journal of Hazardous Materials 158, pp.228-256, (2008).

[3] Hugo Marcelo Veit, Andréa Moura Bernardes a, Jane Zoppas Ferreira, Jorge Alberto Soares Tenório, Célia de Fraga Malfatti, "Recovery of copper from printed circuit boards scraps by mechanical processing and electrometallurgy" Journal of Hazardous Materials B137, pp.1704-1709, (2006).

[4] C. Eswaraiah, T. Kavitha, S. Vidyasagar, S.S. Narayanan,
"Classification of metals and plastics from printed circuit boards (PCB) using air classifier" Chemical Engineering and Processing 47, pp.565-576, (2008).

[5] Jiang $\mathrm{Wu}, \mathrm{Jia} \mathrm{Li}$, Zhenming Xu "Electrostatic separation for multi-size granule of crushed printed circuit board waste using two-roll separator" Journal of Hazardous Materials 159, pp.230-234, (2008).

[6] Jae-Min Yoo, Jinki Jeong, Kyoungkeun Yoo, Jae-chun Lee, Wonbaek Kim, "Enrichment of the metallic components from waste printed circuit boards by a mechanical separation process using a stamp mill" Waste Management 29, pp.11321137, (2009).

[7] O.A. Fouad, S.M. Abdel Basir, "Cementation-induced recovery of self-assembled ultrafine copper powders from spent etching solutions of printed circuit boards" Powder Technology 159, pp.127-134, (2005).

[8] Yanhong Zheng, Zhigang Shen, Chujiang Cai, Shulin Ma, Yushan Xing, "The reuse of nonmetals recycled from waste printed circuit boards as reinforcing fillers in the polypropylene composites" Journal of Hazardous Materials 163, pp.600-606, (2009).

[9] William J. Hall, Paul T. Williams, "Separation and recovery of materials from scrap printed circuit boards" Resources, Conservation and Recycling 51, pp.691-709, (2007).

[10] Chiang Hung-Lunga, Lin Kuo-Hsiung, Lai Mei-Hsiu, Chen Ting-Chien, Ma Sen-Yi, "Pyrolysis characteristics of integrated circuit boards at various particle sizes and temperatures" Journal of Hazardous Materials 149, pp.151159, (2007).

[11] Guido Grause, Masaaki Furusawa, Akitsugu Okuwaki, Toshiaki Yoshioka, "Pyrolysis of tetrabromobisphenol-A containing paper laminated printed circuit boards" Chemosphere 71, pp.872-878, (2008).

[12] Guan Jie, Li Ying-Shun, Lu Mai-Xi, "Product characterization of waste printed circuit board by pyrolysis" J. Anal. Appl. Pyrolysis 83, pp.185-18, (2008). 